\title{
EVALUATION OF ANTIOXIDANT EFFECT OF ALCOHOLIC ROOTS EXTRACT OF EUPHORBIA HIRTA LINN. - IN VITRO
}

\author{
RASHMI WADHWA*, PANKAJ GUPTA
}

\author{
Department of Pharmacy, K.R. Mangalam University, School of Medical and Allied Sciences, Gurgaon, Haryana, India. \\ Email: rashmi1985.rw@gmail.com
}

Received: 01 October 2020, Revised and Accepted: 09 November 2020

\section{ABSTRACT}

Objective: The main objective of the present study was to undergo an investigation on free radical scavenging activity of the roots of Euphorbia hirta Linn. and was compared with a standard antioxidant compound like ascorbic acid.

Methods: Euphorbia hirta roots extract was tested for total flavonoid content, total phenolic content, and in vitro antioxidant activity by 1, 1-diphenyl2-picrylhydrazyl (DPPH) free radical scavenging assay (DPPH) assay, superoxide anion radical scavenging assay, and nitric oxide scavenging assay.

Results: The alcoholic roots extract of $E$. hirta was screened for free radical scavenging and antioxidant activities using three different methods. It was found that percentage inhibition of the extract was concentration-dependent. Total phenolic content and total flavonoid content were found to be $265.72 \pm 1.3$ and $45.67 \pm 1.14$, respectively. The alcoholic extract of $E$. hirta produced a dose-dependent inhibition of superoxide radicals ranging from $40.14 \pm 0.14$ to $70.93 \pm 0.10$. The mean $\mathrm{IC}_{50}$ values for DPPH radical by root extract of $E$. hirta and ascorbic acid were found to be $18.12 \mu \mathrm{g} / \mathrm{ml}$ and $13.17 \mu \mathrm{g} /$ $\mathrm{ml}$, respectively. The alcoholic extract of $E$. hirta produced dose-dependent inhibition of nitric oxide radicals scavenging effect ranging from $17.05 \pm 0.18$ to $51.08 \pm 0.30$. The alcoholic extract of $E$. hirta and ascorbic acid shows mean $\mathrm{IC}_{50}$ values for superoxide radical as $23.64 \mu \mathrm{g} / \mathrm{ml}$ and $14.36 \mu \mathrm{g} / \mathrm{ml}, \mathrm{respectively.}$

Conclusions: The present study showed that E. hirta possesses a considerable amount of both phenolic and flavonoid content. The alcoholic root extract also shows good antioxidant potential. The results of the present study also encourage for further in vivo studies and isolation and characterization of active compounds.

Keywords: Antioxidant, Total phenolic content, Total flavonoid content, Alcoholic extract, In-vitro, Euphorbia hirta.

(C) 2021 The Authors. Published by Innovare Academic Sciences Pvt Ltd. This is an open access article under the CC BY license (http://creativecommons.org/ licenses/by/4.0/) DOI: http://dx.doi.org/10.22159/ajpcr.2021v14i1.39906. Journal homepage: https://innovareacademics.in/journals/index.php/ajpcr

\section{INTRODUCTION}

Euphorbia hirta belongs to the family Euphorbiaceae also known as Dudhi. It is commonly found in open grassland areas and along the roadsides [1]. It grows up to $60 \mathrm{~cm}$ in length with a hairy stem which produces white latex. The leaves are simple, elliptical, and hairy and occur in opposite pairs on the stem. The roots are fibrous, rough, and dark brown in color [2,3]. Conventionally, it is useful for the treatment of bronchial and respiratory diseases, kidney stone, gastrointestinal disorders, and diabetes [4]. It also shows analgesic, antipyretic, antifertility, anxiolytic, and anti-inflammatory activities [5,6]. E. hirta is reported to contain Quercitrin, Afzelin, Myricitrin, 1,3,4,6-tetraO-galloyl- $\beta$-D-glucose, shikimic acid, euphorbin-A, euphorbin-B, euphorbin-C, euphorbin-D, choline, kaempferol, gallic acid, quercitol derivatives, and proto-catechuic acid $[7,8]$. The present study has been designed to investigate the free radical scavenging activity of roots extract of $E$. hirta. Antioxidants are substances which can interfere with the oxidation process by reacting with free radicals [9]. Many synthetic antioxidant compounds such as butylated hydroxyl 0-toluene and butylated hydroxyl anisole show many side effects. Hence, these can be substituted with herbal antioxidants. Herbal products contain a variety of natural chemical constituents which are known as "phytochemicals" such as flavonoids, phenolic compounds, and tannins which are reported to act as radical scavengers [10]. Hence the interest in herbal antioxidants has greatly increased in recent years $[11,12]$. Our literature survey revealed that there is no evidence of the antioxidant effect of the roots of this plant. Therefore, the present study was carried out to investigate the in vitro antioxidant potential of roots extract of E. hirta. The present study evaluates total phenolic content, total flavonoid content, and antioxidant activity of alcoholic extract of roots of E. hirta.

\section{MATERIALS AND METHODS}

\section{Collection of plant material}

The roots of E. hirta were collected in the month of August 2019 from Hodal, India. A voucher specimen has been retained at the School of Medical and Allied Sciences, K.R. Mangalam University, Sohna Road, Gurgaon. The roots were cleaned thoroughly with distilled water to remove any type of contamination. Then, washed roots were air-dried in shade.

\section{Extraction using Soxhlet apparatus}

To prepare roots extract of $E$. hirta Linn, the dried roots were powdered using dry grinder and passed through the sieve. Then, this powder was packed into Soxhlet apparatus and extracted successively with alcohol. The process was continued until the solvent in the thimble becomes transparent. The extract was solidified under reduced pressure in a rotary evaporator to produce a semisolid mass and stored in airtight containers in a refrigerator below $10^{\circ} \mathrm{C}[13]$.

\section{Determination of Total phenol content}

The total phenolic content of the alcoholic extracts of E. hirta was determined by the Folin-Ciocalteu method [14,15]. $0.2 \mathrm{ml}$ of extract $(1.0 \mathrm{mg} / \mathrm{l})$ in alcohol and $0.1 \mathrm{ml}$ of Folin-Ciocalteu reagent were mixed thoroughly and the mixture was allowed to stand for $15 \mathrm{~min}$ and then $2.0 \mathrm{ml}$ of $20 \%(\mathrm{w} / \mathrm{v})$ sodium carbonate solution was added. The mixture was further incubated for $60 \mathrm{~min}$ at room temperature. The total phenolic content was determined at $650 \mathrm{~nm}$. The total phenolic content was calculated from the calibration curve which was made by preparing $1 \mathrm{ml}$ aliquots of $100,200,300,400$, and $500 \mu \mathrm{g} / \mathrm{ml}$ solutions of gallic acid, the results were expressed as gallic acid equivalents per gram of the sample. 


\section{Determination of total flavonoid content}

The total flavonoid content of the alcoholic extract of E. hirta was determined by aluminum chloride colorimetric method [16]. $50 \mu \mathrm{l}$ of extract of $E$. hirta (1 $\mathrm{mg} / \mathrm{ml}$ ethanol) was made up to $1 \mathrm{ml}$ with methanol and mixed with $0.3 \mathrm{ml}$ of $10 \%$ aluminum chloride, $0.3 \mathrm{ml}$ of $5 \% \mathrm{NaNo}_{2}$ solution, and $4.0 \mathrm{ml}$ of distilled water. Then, this mixture was allowed to rest for $30 \mathrm{~min}$ at room temperature. The absorbance of all the mixtures was measured at $510 \mathrm{~nm}$ against blank containing water instead of the sample. Quercetin acts as a standard compound for the measurement of total flavonoids. The total flavonoid content was calculated from a calibration curve and results were expressed as $\mathrm{mg} / \mathrm{g}$ of quercetin equivalents of plant extract.

\section{Antioxidant activity: In-vitro}

\section{1, 1-diphenyl-2-picrylhydrazyl (DPPH) radical scavenging assay}

DPPH radical scavenging activity of the E. hirta roots extract was measured by decreasing the absorbance of methanol solution of DPPH [17]. A DPPH stock solution (35 mg/l) was prepared using methanol and $5 \mathrm{ml}$ of this stock solution was added to $1 \mathrm{ml}$ of $E$. hirta roots extract solution at different concentrations $(10-50 \mu \mathrm{g} / \mathrm{ml})$. After $30 \mathrm{~min}$, absorbance was measured at $517 \mathrm{~nm}$ and compared with standard. Scavenging activity was expressed as the percentage inhibition calculated using the following formula:

$\mathrm{DPPH}$ radical scavenging activity $=[$ Abs control - Abs sample $] /[$ Abs control] $\times 100$

Where Abs control - absorbance values of the blank sample.

Abs sample - absorbance values of alcoholic extract of E. hirta.

The antiradical activity was expressed in terms of the amount of antioxidant necessary to decrease the initial DPPH absorbance by $50 \%$ $\left(\mathrm{IC}_{50}\right)$.

\section{Superoxide radical scavenging assay}

For measurement of superoxide radical scavenging activity of alcoholic extract of $E$. hirta, $1 \mathrm{ml}$ of test solution of $E$. hirta roots extract at different concentrations $(10-50 \mu \mathrm{g} / \mathrm{ml})$ was mixed with the reaction mixture. The reaction mixture consists of $1 \mathrm{ml}$ of nitro blue tetrazolium (NBT) solution (156 mM NBT in phosphate buffer, pH 7.4) and $1 \mathrm{ml}$ of nicotinamide adenine dinucleotide (NADH) (468 mM NADH in phosphate buffer, $\mathrm{pH}$ 7.4). Then, $100 \mathrm{ml}$ of phenazine methosulfate (PMS) solution (60 mM PMS in phosphate buffer, pH 7.4) was added to the mixture to start the reaction. Then, this reaction mixture was incubated at $25^{\circ} \mathrm{C}$ for $5 \mathrm{~min}$ and the absorbance of the reaction mixture was measured at $560 \mathrm{~nm}$ against blank sample and compared with standard. A decrease in the absorbance of reaction mixture indicates the increased superoxide anion scavenging activity [18-20]. The degree of scavenging activity was calculated as a scavenging percentage and $\mathrm{IC}_{50}$ value was calculated.

Inhibition $(\%)=$ (Absorbance Control -Absorbance Sample / Absorbance Control) $\times 100$

Where Abs control - absorbance values of the blank sample.

Abs sample - absorbance values of alcoholic extract of E. hirta

\section{Nitric oxide scavenging activity}

For measurement of nitric oxide scavenging activity, sodium nitroprusside in phosphate-buffered saline was mixed with different concentrations of the extract $(10-50 \mu \mathrm{g} / \mathrm{ml})$ dissolved in methanol and incubated at $25^{\circ} \mathrm{C}$ for $30 \mathrm{~min}$. In control, test compound was not added, but same amount of methanol was taken. Then, this solution was incubated for $30 \mathrm{~min}$. $1.5 \mathrm{ml}$ of this incubated solution was taken and mixed with $1.5 \mathrm{ml}$ of Griess reagent (1\% sulfanilamide, $2 \%$ phosphoric acid, and $0.1 \% \mathrm{~N}$-1-naphthylethylenediamine dihydrochloride). The absorbance was measured at $546 \mathrm{~nm}$ and compared with standards. The percentage scavenging activity was measured with reference to standard [21]. The degree of scavenging activity was calculated as a scavenging percentage. $\mathrm{IC}_{50}$ value was calculated.

Inhibition $(\%)=[$ Absorbance Control-Absorbance Sample/Absorbance Control] $\times 100$.

Where Abs control - absorbance values of the blank sample.

Abs sample - absorbance values of alcoholic extract of $E$. hirta.

\section{Statistical analysis}

The data was expressed as mean \pm standard deviation (SD). The Student's t-test was used to test the significance of differences between results obtained from different samples and between results from samples and controls. A probability value of $<0.05$ was considered as significant.

\section{RESULTS}

Determination of total phenol and total flavonoid content Phenolic and flavonoid compounds are widely distributed in plants, where they act as antioxidants and free radical scavenging agents. Phenolic compounds are the most abundant class of secondary metabolites in plants. A plant phenolic compound plays an important role in growth, pigmentation, and reproduction of plant and also can act as an antioxidant. Flavonoids are the most important plant pigments responsible for producing colored pigmentation responsible to attract animals for pollination. Furthermore, in higher plants, flavonoids are involved in ultraviolet screening. Work done on flavonoid derivatives has shown various activities such as antibacterial, anti-inflammatory, antiviral, and anticancer activities. The aim of this study was to determine the total phenolic and flavonoid content and the antioxidant activity of roots extract of E. hirta.

Total phenolic content was measured using the Folin-Ciocalteu reagent in the extract. Total phenols are expressed as Gallic acid equivalent. Total flavonoids content in plant extracts was determined using aluminum chloride colorimetric method and total flavonoid is expressed as mg of total flavonoid content/g of sample. The total phenolic content in alcoholic extract was found to be $265.72 \pm 1.3$ and total flavonoid content of alcoholic extract of $E$. hirta extract was found to be $45.67 \pm 1.14$, as shown in Table 1.

\section{Evaluation of in vitro antioxidant activity}

Determination of DPPH radical scavenging activity

Antioxidant activity of $E$. hirta was evaluated by various in-vitro methods. DPPH radical was used as a substrate to evaluate the free radical scavenging activity of alcoholic root extract. This process involves a reaction of a specific antioxidant with a free radical DPPH and this causes a decrease in the concentration of DPPH by antioxidant, which decreases the absorbance of DPPH at $517 \mathrm{~nm}$. Ascorbic acid was used as standard. The scavenging effect of root extract of $E$. hirta on the DPPH radical was found to be $80.14 \pm 0.18$ at a concentration of $50 \mu \mathrm{g} / \mathrm{ml}$ as given in Table 2. These results indicate that extract has a marked effect on scavenging free radicals.

Determination of superoxide radical scavenging activity

The reductive capabilities of extract were compared with ascorbic acid which is taken as standard. It also shows scavenging of superoxide anion derived from dissolved oxygen by PMS-NADH coupling reaction. A decrease in the absorbance of the mixture at $560 \mathrm{~nm}$ with

Table 1: Total phenolic content and total flavonoid content of alcoholic extract of Euphorbia hirta

\begin{tabular}{lll}
\hline Extracts & $\begin{array}{l}\text { Total phenolic content } \\
\text { (mg of GAE/g) }\end{array}$ & $\begin{array}{l}\text { Total flavonoid } \\
\text { content }(\mathbf{m g} \text { of } \mathbf{Q E} / \mathbf{g} \text { ) }\end{array}$ \\
\hline Alcoholic extract & $265.72 \pm 1.3$ & $45.67 \pm 1.14$ \\
\hline $\begin{array}{l}\text { Values represent mean } \pm \text { SD }(\mathrm{n}=6) . \text { Total phenols are expressed as Gallic acid } \\
\text { equivalent. Total flavonoid are expressed as mg of total flavonoid content/g of } \\
\text { sample Where GAE: Gallic acid equivalent, QE: Quercetin equivalent }\end{array}$
\end{tabular}


antioxidants shows the consumption of superoxide anion in the reaction mixture [22]. The percentage inhibition of superoxide generation by 50 $\mu \mathrm{g} / \mathrm{ml}$ concentration of roots extract was measured as $70.93 \pm 0.10$. The superoxide scavenging activity of an extract of $E$. hirta and standard ascorbic acid was shown in Table 3. These results indicate that extract has a marked effect on scavenging the free radicals. Alcoholic extract of $E$. hirta shows a superoxide scavenging activity with an $\mathrm{IC}_{50}$ value $23.64 \mu \mathrm{g} / \mathrm{ml}$.

\section{Determination of nitric oxide scavenging activity}

In the nitric oxide scavenging assay, crude extract of the root was evaluated for its inhibitory effect on nitric oxide production and ascorbic acid is used as standard. Alcoholic roots extract at 10, 20, 30, 40 , and $50 \mu \mathrm{g} / \mathrm{ml}$ concentration produced $17.05 \pm 0.18,23.29 \pm 0.20$, $34.43 \pm 0.10,43.57 \pm 0.16$, and $51.08 \pm 0.30$ percentage of inhibition, as shown in Table 4. Antioxidant activities $\left(\mathrm{IC}_{50}\right)$ of the $E$. hirta extract and ascorbic acid were calculated in all the methods (Table 5).

Table 2: 1, 1-diphenyl-2-picrylhydrazyl radical scavenging activity of alcoholic extract of Euphorbia hirta and ascorbic acid

\begin{tabular}{lll}
\hline Concentration $\boldsymbol{\mu g} / \mathbf{m l}$ & \multicolumn{2}{l}{ \% Inhibition } \\
\cline { 2 - 3 } & Ascorbic acid & Alcoholic extract \\
\hline 10 & $46.17 \pm 0.02$ & $41.07 \pm 0.06$ \\
20 & $57.24 \pm 0.06$ & $50.77 \pm 0.1$ \\
30 & $68.32 \pm 0.09$ & $64.53 \pm 0.14$ \\
40 & $79.82 \pm 0.2$ & $73.18 \pm 0.02$ \\
50 & $88.26 \pm 0.07$ & $80.14 \pm 0.18$ \\
\hline
\end{tabular}

Values are expressed as mean $\pm \operatorname{SD}(n=6)$

Table 3: Superoxide radical scavenging activity of alcoholic extract of Euphorbia hirta and ascorbic acid

\begin{tabular}{lll}
\hline Concentration $\boldsymbol{\mu g} / \mathbf{m l}$ & \multicolumn{2}{l}{ \% Inhibition } \\
\cline { 2 - 3 } & Ascorbic acid & Alcoholic extract \\
\hline 10 & $47.27 \pm 0.13$ & $40.14 \pm 0.14$ \\
20 & $52.34 \pm 0.29$ & $46.18 \pm 0.18$ \\
30 & $66.82 \pm 0.17$ & $55.30 \pm 0.05$ \\
40 & $77.78 \pm 0.49$ & $62.05 \pm 0.02$ \\
50 & $85.57 \pm 0.16$ & $70.93 \pm 0.10$ \\
\hline
\end{tabular}

Values are expressed as mean $\pm \operatorname{SD}(n=6)$

Table 4: Nitric oxide scavenging activity of alcoholic extract of Euphorbia hirta and ascorbic acid

\begin{tabular}{lll}
\hline Concentration $\boldsymbol{\mu g} / \mathbf{m l}$ & \multicolumn{2}{l}{ Inhibition } \\
\cline { 2 - 3 } & Ascorbic acid & Alcoholic extract \\
\hline 10 & $29.17 \pm 0.3$ & $17.05 \pm 0.18$ \\
20 & $35.10 \pm 0.16$ & $23.29 \pm 0.20$ \\
30 & $47.54 \pm 0.10$ & $34.43 \pm 0.10$ \\
40 & $57.26 \pm 0.17$ & $43.57 \pm 0.16$ \\
50 & $68.20 \pm 0.30$ & $51.08 \pm 0.30$ \\
\hline
\end{tabular}

Values are expressed as mean \pm SD $(n=6)$

Table 5: Antioxidant activities (IC ${ }_{50}$ ) of alcoholic extract of Euphorbia hirta and ascorbic acid

\begin{tabular}{llll}
\hline $\begin{array}{l}\text { Standard/ } \\
\text { extracts }\end{array}$ & $\mathbf{I C}_{\mathbf{5 0}}$ value $\boldsymbol{\mu g} / \mathrm{ml}$ & & \\
\cline { 2 - 4 } & $\begin{array}{l}\mathbf{1}, \mathbf{1}-\text { diphenyl-2- } \\
\text { picrylhydrazyl }\end{array}$ & $\begin{array}{l}\text { Superoxide } \\
\text { radical assay }\end{array}$ & $\begin{array}{l}\text { Nitric oxide } \\
\text { scavenging assay }\end{array}$ \\
\hline $\begin{array}{l}\text { Ascorbic } \\
\text { acid }\end{array}$ & 13.17 & 14.36 & 32.54 \\
$\begin{array}{l}\text { Alcoholic } \\
\text { root } \\
\text { extract }\end{array}$ & 18.12 & 23.64 & 41.46 \\
\hline
\end{tabular}

Values are expressed as mean \pm SD $(n=6)$

\section{DISCUSSION}

The alcoholic roots extract of E. hirta was screened for free radical scavenging and antioxidant activities using three different methods. It was found that percentage inhibition of the extract was concentration dependent. This study shows that plant extract contains phytochemical constituents that are capable of scavenging free radicals. The plant shows a significant antioxidant effect in a dose-dependent manner with an $\mathrm{IC}_{50}$ value comparable to that of the drug ascorbic acid. The antioxidant activity of roots may be due to its active constituents such as flavonoids, tannins, and alkaloids. Thus, the present study demonstrates that alcoholic extract has a marked antioxidant effect.

\section{CONCLUSION}

The E. hirta is an important medicinal plant as it has many medicinal uses in traditional medicine. The present study shows that $E$. hirta possesses a considerable amount of both phenolic and flavonoid content. The alcoholic roots extract also shows good antioxidant potential. The antioxidant activity of roots may be attributed to its phenolic and flavonoid content. However, the exact constituents of E. hirta root extract which shows the antioxidant activity are yet to be investigated. The results of the present study also encourage for further in vivo studies, isolation, and characterization of active compounds. Hence, in the future, further studies are needed to isolate and identify the active constituents responsible for such activity.

\section{AUTHORS' CONTRIBUTIONS}

The corresponding author performed collection of plant, extraction, experimental work, analysis of data, and wrote the manuscript. The coauthor helped in evaluating the final manuscript. All the authors have read and agreed on the final approval of the manuscript.

\section{CONFLICTS OF INTEREST}

The author's declared that they have no conflicts of interest in publishing this research article.

\section{AUTHORS' FUNDING}

This work is completely self-funded.

\section{REFERENCES}

1. Kumar S, Malhotra R, Kumar D. Euphorbia hirta: Its chemistry, traditional and medicinal uses, and pharmacological activities. Pharmacogn Rev 2010;4:58-61.

2. Kumar S, Malhotra R, Kumar D. Antihyperglycemic, antihyperlipidemic and antioxidant activities of Euphorbia hirta stem extract. Int Res J Pharm 2010;1:150-6.

3. Williamson EM. Major Herbs of Ayurveda. China: Churchill Livingstone; 2002.

4. Kumar S, Malhotra R, Kumar D. Antidiabetic and free radicals scavenging potential of Euphorbia hirta flower extract. Indian J Pharm Sci 2010;72:533-7.

5. Kumar S, Malhotra R, Kumar D. Evaluation of antidiabetic activity of Euphorbia hirta Linn. in streptozotocin induced diabetic mice. Indian J Nat Prod Resour 2010;1:200-3.

6. Rajeh MA, Zuraini Z, Sasidharan S, Latha LY, Amutha S. Assessment of Euphorbia hirta L. leaf, flower, stem and root extracts for their antibacterial and antifungal activity and brine shrimp lethality. Molecules 2010;15:6008-18.

7. Rastogi RP, Mehrotra BN. Compendium of Indian Medicinal Plants. Vol. 3. Lucknow, India: Central Drug Research Institute; 2002.

8. Rastogi RP, Mehrotra BN. Compendium of Indian Medicinal Plants. Vol. 4. Lucknow, India: Central Drug Research Institute; 2002.

9. Trenam CW, Blake DR, Morris CJ. Skin inflammation: Reactive oxygen species and the role of iron. J Invest Dermatol 1992;99:675-82.

10. Xie B, Shi H, Chen Q, Ho CT. Antioxidant properties of fractions and polyphenol constituents from green, oolong and black teas. Proc Natl Sci Counc Repub China B 1993;17:77-84.

11. Usha B, Pushpalatha KC. In vitro antioxidant activity and phytochemical screening of leaf extracts of Grewia heterotricha mast. Int J Curr Pharm Res 2016;8:68-72. 
12. Shahidi F, Wanasundara PK. Phenolic antioxidants. Crit Rev Food Sci Nutr 1992;32:67-103.

13. Harborne JB. Phytochemical Methods-A Guide to Modern Techniques of Plant Analysis. $1^{\text {st }}$ ed. London, UK: Chapman and Hall; 1998

14. Renuka K, Devi VR, Subramanian SP. Phytochemical screening and evaluation of in vitro antioxidant potential of immature palmyra palm (Borassus flabellifer linn.) fruits. Int J Pharm Pharm Sci 2018;10:77-83.

15. Miliauskas G, Venskutonis PR, Van Beek TA. Screening of radical scavenging activity of some medicinal and aromatic plant extracts. Food Chem 2004;85:231-7.

16. Chang C, Yang M, Wen H, Chern J. Estimation of total flavonoid content in propolis by two complementary colorimetric methods. J Food Drug Anal 2002;10:178-82.

17. Govindarajan R, Rastogi S, Vijayakumar M. Studies on the antioxidant activities of Desmodium gangeticum. Bio Pharm Bull 2003;26:1424-7.
18. Nishikimi M, Rao NA, Yagi K. The occurrence of superoxide anion in the reaction of reduced phenazine methosulfate and molecular oxygen. Biochem Biophys Res Commun 1972;46:849-53.

19. Gülçin I, Alici HA, Cesur M. Determination of in vitro antioxidant and radical scavenging activities of propofol. Chem Pharm Bull (Tokyo) 2005;53:281-5.

20. Sánchez-Moreno C, Larrauri JA, Saura-Calixto F. Free radical scavenging capacity and inhibition of lipid oxidation of wines, grape juices and related polyphenolic constituents. Food Res Int 1999;32:407-12.

21. Rashmi, Kumar S, Singh J, Choudhary M, Kumar D. Antioxidant and analgesic activities of Valerian officinalis linn. Root extract. Pharmacologyonline 2009;2:230-41.

22. Jayanthi P, Lalitha P. Reducing power of the solvent extracts of Eichhornia crassipes (Mart.) Solms. Int J Pharm Pharm Sci 2011;3:126-8. 